The Geneva Papers on Risk and Insurance, 17 (No. 63, April 1992), 208-214

\title{
The Uruguay Round and the Liberalization of Trade in Insurance Services
}

\author{
by Mario A. Kakabadse*
}

\section{Introduction}

The GATT or General Agreement on Tariffs and Trade is a multilateral treaty containing reciprocal rights and obligations based on a few trading principles which include non-discrimination among members, equality of treatment for foreign and domestic products, transparency and predictability of trade barriers, the commitment to liberalize trade, and consultation between trading partners to solve disputes. GATT is now over forty years old and has a large membership, currently 100 countries are full members or Contracting Parties as they are called, and there is a considerable queue to join.

GATT is also a forum for bargaining and negotiating the reduction of tariffs and other barriers to trade. The current round of trade negotiations is the Uruguay Round launched in Uruguay in September 1986, the most ambitious and complex negotiating round to date, covering both trade in goods and, for the first time, trade in services.

The subject matter of the Uruguay Round is complex and the interests of the 100 plus participating countries diverse. It is worthwhile recalling that the principle objectives of the Round are fourfold: first, to achieve a significant liberalization of trade in goods; second, to strengthen GATT's institutional machinery; third, to reinforce and improve GATT rules relating to conditions of competition; and fourth, to establish new multilateral disciplines in regard to intellectual property protection, trade-related investment measures and, in particular, to the expansion and liberalization of trade in services.

After more than five years of negotiations, participants have before them a 435-page proposed agreement containing, in effect, a blueprint for the multilateral trading system into the 21 st century. The complex package on offer strengthens trading rules and their enforcement by the GATT, lowers barriers to foreign goods and services and extends, for the first time, fair trade rules to services which now account for nearly 20 per cent of world trade.

\footnotetext{
* Counsellor, GATT Geneva. The views expressed in this paper are those of the author and do not necessarily reflect the position of the organisation for which he works.
} 


\section{Negotiations on services}

An agreement on services is designed to extend internationally agreed rules to world trade in services - covering a wide range of businesses from banking and insurance to tourism and travel. This trade is conservatively estimated to be worth around $\$ 800$ billion dollars a year or nearly 20 per cent of total world trade. The largest and fastest growing component of services trade is commercial services including telecommunications, banking, insurance and advertising, which are critical ingredients in the process of economic growth and development, as well as international competitiveness in both services and goods trade.

In recent years such services have become increasingly marketed internationally, both through cross-border flows of services and via their sale through a local presence. This has been a result of dramatic developments in communications and information-based technologies, rapid growth in the importance of many multinational business services activities and the worldwide trend towards deregulation and privatization of state-owned services providers.

The negotiations amount to the first attempt in forty years to write a major multilateral trade agreement. Yet this is no easy task: there is little research on the subject and no convincing theory of trade in services; statistics are poor; trade rules would have to cover services which are very heterogeneous in nature ranging from banking to broadcasting, from architecture to advertising; they are traded in various ways - for some services the customer has to be in close proximity to the supplier (think of tourism, transport and surgery), for others there can be more distance - look at computing services or broadcast entertainment that can be communicated by electronic means; above all, restrictions to services trade are hidden and therefore difficult to negotiate away: the customs tariff cannot be applied to services as national interests are protected mainly by domestic regulations.

The aim of liberalizing trade in services by dismantling barriers and opening services markets to foreign competition is based on the view that the potential for a larger role for services in world trade could be increased by agreeing on multilateral rules to govern international transactions in services.

This view, coupled with the recent internationalisation of services, explains the motivation which led some 100 trade ministers meeting in Punta del Este in Uruguay in September 1986 to agree to establish a multilaterally agreed set of concepts, principles and rules for trade in services, with three objectives:

- the creation of a multilateral framework which would include the elaboration of possible disciplines on trade policy in individual sectors;

- the expansion of trade in services under conditions of transparency and progressive liberalization, and

- the promotion, through such trade expansion, of the economic growth of all trading partners and the development of developing countries.

It is the task of fulfilling these objectives which has been the driving force behind the negotiations which have proceeded on three fronts: drafting the multilateral rules that would govern trade in services, establishing, where necessary, any specialized sectoral rules and beginning the actual process of liberalization. 


\section{(i) The multilateral framework}

Since 1987, there have been continuous negotiations to cstablish a multilaterally agreed framework of rules and principles. Between the Punta del Este and the Brussels Ministerial meetings, a Group for Negotiations on Services (GNS), consisting of over one hundred countries, met formally on over 30 occasions to draft the framework, in addition. thcre have bcen innumerable informal meetings with the same objective.

The General Agreement on Trade in Services consists of:

- A multilateral framework containing 35 articles and five annexcs; the annexcs rclate to Article II (i.e. m.f.n.) exemptions, Movement of Natural Persons providing Services under the Agreement, Financial Scrvices, Telecommunications, and Air Transport;

- Other relevant documents which comprise the Ministerial Dccisions on Institutional Arrangements and on Ccrtain Dispute Settlement Procedurcs, Decision conccrning Article XIV(b) (exceptions), Understanding on Commitments in Financial Services and Substantive Guidelines for the Negotiation of Initial Commitments during the Uruguay Round.

With regard to the main features of the agreement, a number of traditional trade principles would apply for services covered by the agrecment. The main ones are:

- Non-discrimination between countries; this means that all signatories to the agreement must be given the most favourable trading terms available to other trading partners.

- The agreement would entail the introduction of equal treatment of foreign and domestic services companies, known as national treatment in GATT jargon. Let me add that signatories will be ablc to negotiate which of their specific serviccs they do not want subjected to this obligation.

- The agreement would lead to more transparency of the rules, regulations and procedures which affect trade in services. Given the prevalence and complexity of rcgulations, as well as the scope of administrative discretion in applying them, transparency is particularly important in the provision of insurance services.

- The agreement will be a long-term undertaking, aimed at the progressive lowering of trade barriers. There will be appropriate flexibility for countries to gradually lower barriers to trade. Thus, for example, those participants which were until rccently centrally planned economies may start from a position in which insurance institutions have been shielded from competition for many ycars. They may, for example, need longer to adapt their insurance systems to a change in compctitive conditions than traditional markct-oricnted countries.

Regarding the scope of the agrecment, governments have agreed that the framework will cover a wide range of possibilities for selling scrvices in forcign markets. Thus, not only insurance services where the provision of the service is cross-border in nature, but also those transactions wherc business is conducted via a foreign presence in the importing country fall within the scope of the agreement. With access for forcign insurance servicc suppliers in the domestic market on the negotiating table, measures limiting the size of the domestic markct available to foreign suppliers, as wcll as dircct restrictions on cross-border activities, will be the subject of negotiations.

Other rules cover subsidies, regional trading blocks, the settlcment of disputes, safeguards and exceptions, as well as the mechanics of the actual negotiating or bargaining 
process. So much for the broad outline of the agreement. At the present stage there are a number of articles that require further work to complete the framework, and this work is now being taken up.

\section{(ii) Sectoral annexes}

At the time of the Brussels meeting, draft sectoral annexes were in place for a number of sectors and while there was agreement among governments on the need for a financial and insurance services annex, the nature and content of even a draft annex could not be agreed. The annex forwarded to Brussels for negotiation was literally a blank sheet of paper with a footnote acknowledging the need for an annex, but the main points of agreement and disagreement were well-known.

Governments have agreed that the financial services sector including insurance has its own peculiarities that need to be taken into account. The role of regulations concerning prudential standards, for example, need to be provided for in the specific commitments to be negotiated. There is also agreement that all insurance and insurance-related services should be covered, namely: direct insurance (life and non-life), reinsurance and retrocession; insurance intermediation such as brokerage; and auxiliary services such as actuarial and risk assessment services. One of the basic points of contention remains the role of the annex in establishing the extent and nature of the liberalization commitments undertaken and whether a higher level of liberalization should be achieved in the financial services sector compared to other services sectors.

\section{(iii) Initial commitments}

Finally, the agreement on the framework and sectoral annexes would have little operational value in the absence of commitment to liberalize on the part of all signatures. To this effect, participating countries have begun to submit conditional offers which would bind parts of national regulatory regimes in respect of measures applying to trade in services. This means essentially that countries would undertake to maintain or improve current levels of openness of market access and operating conditions.

These commitments are to be inscribed in so-called schedules to be appended to the services agreement and would enter into force as an integral part of the GATS. Subsequent negotiations between countries would be directed to the reduction or elimination of restrictions on trade in services. The idea here is to give international service providers progressively more liberal market access and more equitable operating conditions.

At present, countries accounting for most of world trade in services have come forward with offers to liberalize trade in various sectors including insurance. Many other smaller countries are in the process of preparing their offers. Bilateral negotiations are presently underway to clarify and improve offers and, at a later stage, to turn the offers into binding commitments. It is worth stressing that several participants have expressed that the acceptability of the multilateral framework depends on the initial level of negotiated commitments of signatories.

\section{Sectoral implications of the services agreement}

There are details still to be worked out but the principles and general shape of a services agreement are now clear. There are important implications of this emerging agreement for the insurance service sector which deserve mention. 


\section{Coverage of insurance services}

The final sectoral coverage of the agreement is not yet decided but it was agreed by Trade Ministers at thc Montreal Mid-Term Review in Dccember 1988 that no sector should be excluded. It is clear though, that liberalization in world trade in insurance services is high on the priority list for all countries - developed and developing alike. The agreement is thereforc likely to cover the main sectors of the international insurance industry, namely:

- Reinsurance and international transport or cargo insurance which are the most inherently international parts of the insurance industry.

- A lcss inherently international elcment rclating to the insurance purchased both at home and abroad by large business enterprises against liability, casualty and property risks.

- General insurance which includes a wide variety of business in the industrial, commercial and personal sectors, including : fire, product liability, professional ncgligence, loss of profits, third party public risks, employers' liability, householder, house-owner, motor vehicle (personal injury and damage to vehicle and property), travel, sickness and accident. (Much of this insurance is usually purchased locally from insurance companies that have established themselves in the national market subject to the applicable national regulations. Foreign enterprises are generally obliged to acquire local facilities in order to sell to this part of the market.)

- Life insurance which is considered by many countries to be an important source of savings to be channelled into domestic investment projects. Life insurance comprises operations based on capitalization, including: survival or death insurance, permanent health insurance, annuities, supplementary insurance against special personal injury or sickness, capital redemption operations, management of pension funds, etc.

\section{Definition of trade in insurance services}

Governments have agreed that the framework will cover a wide range of possibilities for selling services in foreign markets. It will apply to all types of services trade whether supplied across frontiers, at home to foreign customers, or by foreign companies in foreign markets (which would involve the cross-border movement of capital and labour).

International trade in insurance occurs both through cross-border movements of insurance services (where there is no requirement to establish or to maintain funds in the importing country), as well as through cross-border movements of production factors such as that involved in the cstablishment by insurancc enterprises of production and marketing outlets in foreign markets. More specifically, this could cover:

(a) Insurance sold directly from abroad, apart from that involving international transportation, generally relates to large or accumulatcd risks which cannot bc placed locally, to reinsurance, or to the worldwide insurance of multinational busincsses opcrating abroad. Cross-border trade is mainly limited to non-life insurance business which has incrcasingly taken the form of reinsurance.

(b) Other than for reinsuratice, some form of foreign presence through branches, agencies or subsidiarics is usually neccssary for firms to be able to market most kinds of insurance policy on a significant scale. Frequently, such a situation derives from government regulations which prohibit firms from canvassing and sclling policies to residents from a base abroad. Typically, government regulations specify the minimum capital the 
foreign insurer must hold within the country's borders in order to enjoy some form of local presence in that market. The type of foreign commercial presence can vary depending on the nature of establishment chosen or permitted. Even though foreign insurers may be wholly excluded from a market, the market share of foreign insurance firms established in certain economies may vary widely, in a few cases reaching over 50 per cent in some segments of the market.

\section{Trade liberalization principles applied to insurance services}

The question of what kind of "trade barriers" to insurance services could be reduced by the agreement is not yet completely decided for any service sector but this is clearly at the heart of how services markets will be progressively opened up, or in the language of GATT, how "concessions will be exchanged" between those countries prepared to offer market access in their services sectors while requesting market access elsewhere.

On the grounds of consumer protection and domestic control over the economy, virtually all governments impose laws, regulations and practices which have restrictive effects on market entry and operation with regard to foreign insurers. Several such measures directly restrict the supply of foreign insurance services by means of local establishment or across national frontiers, or impede residents from purchasing their insurance abroad. Other measures and practices indirectly limit the foreign provision of insurance services by making it more onerous for foreign insurers to sell their services and more costly for nationals to buy them. Significant regulations and measures in this regard are:

- Measures affecting cross-border trade : many countries restrict or prohibit residents from placing any insurance contracts with non-established insurance companies - i. e., insurers not licensed to carry out insurance transactions within that country. This is particularly the case with compulsory insurance such as for motor vehicles which is generally purchased only from domestically authorized insurers.

- Measures relating to establishment: investment controls implemented because of the concern that foreign firms could gain a dominant share of a key sector of the national economy. Although most countries do not completely prohibit establishment, they may require that insurers obtain prior authorization usually in the form of a licence for each class of insurance they wish to sell.

- Measures relating to operating and competitive conditions: certain measures may affect the financial conditions under which insurers operate in foreign markets. Exchange control regulations, by delaying or allowing remittances abroad only at unfavourable rates of exchange, can have adverse effects on the repatriation of profits of foreign insurers. Other measures that may have discriminatory effects are those relating to minimum capital, solvency and deposit requirements as well as investment regulations which may be more stringent than those applying to domestically-owned insurers.

For liberalization to be effective, a number of GATS concepts, principles and rules need to be applied, such as non-discrimination, national treatment and transparency. Thus, countries would agree not to discriminate between suppliers of the same service from different countries. Once the service and its provider have entered another country, they should receive treatment that places them on an equivalent competitive footing as domestic suppliers. Furthermore, any rules affecting trade in services should be published to ensure a reasonable level of transparency. 
Progressive liberalization of cross-border trade could mean, for example, that certain restrictions relating to the taxation of insurance business underwritten by foreign, nonestablished firms be gradually reduced. Licenses to cstablish locally, for example, could be granted to a progressively larger number of foreign firms and licenses to engage in certain lines of business could be granted in a similar fashion.

The implications of national treatment in the insurance scrvices sector may vary depending on whether it applied only to cross-border transactions or to services produced locally by a foreign firm. In the former case (i. e. the direct placement of insurance contracts abroad), national treatment could apply to taxation measures affecting consumers placing their insurance with foreign, non-established firms. Application of national treatment to delivery through local prescnce could imply the reduction of discrimination against foreign insurers regarding deposit, taxation and other requirements, with a view towards allowing them to operate in the market on the same competitive terms as domestic insurers.

Considerations relating to market access through local establishment might cover the outright exclusion of foreign insurance firms from national markets or the requirement of prior authorization for the undcrtaking of business in certain classes of insurance. Measures such as minimum capital, solvency, deposit and investment regulations might affect access to a market and could be relevant in the context of market access commitments.

\section{Outlook}

In the Uruguay Round, countries are on the threshold of a General Agreement on Trade in Services, the aim being to extend internationally agreed rules to trade in services which would be the basis for reducing trade barriers and opening markets to foreign competition. It must be emphasized, however, that the object of the liberalization negotiations is not deregulation of insurance and other financial services per se, but a commitment to regulate in ways which will progressively limit discrimination against foreign insurance service providers. Nevertheless, all participants in the negotiations recognize that the financial services industry has unique characteristics relating, in particular, to the safety and soundness concerns of financial regulatory authorities in each country. Thus, countries are, at the same time as embarking on liberalization negotiations, seeking to ensure that the degree of liberalization achieved is compatible with the soundness and stability of financial markets.

\section{REFERENCES}

Part II of the Ministerial Declaration on the Uruguay Round, Negotiations on Trade in Services, Punta del Este, Uruguay, 20 September 1986 in News of the Uruguay Round, GATT, October 1986.

Offers at a Glance: An Outline of Preliminary Commitments in the GATT Negotiations on Services. Coalition of Service Industries, Inc., Washington D.C., August 1991. 